\title{
Inhibitive effect of 1,3,4-thiadiazole-2,5-dithiol on copper corrosion in chloride media
}

\author{
S. Echihi, ${ }^{1,2^{*}}$ M. Tabyaoui ${ }^{2}$ and W. Qafsaoui ${ }^{1 *}$ \\ ${ }^{1}$ Laboratory of Water and Environment, Faculty of Sciences, BP 20, 24000, El Jadida, \\ Morocco \\ ${ }^{2}$ Laboratory of Nanotechnology, Materials and Environment, Faculty of Sciences, \\ Av. Ibn Battouta, BP 1014 RP, M-10000, Rabat, Morocco \\ *E-mail: wqafsaoui@gmail.com; echihisiham@gmail.com
}

\begin{abstract}
Corrosion inhibition of copper by 1,3,4-thiadiazole-2,5-dithiol (DMTD) was investigated in $0.1 \mathrm{M} \mathrm{NaCl}$ solution using electrochemical methods, surface and solution analysis. Polarization tests results showed that DMTD inhibits efficiently copper corrosion, prevents oxide formation and revealed a marked effect of mixed inhibition after $1 \mathrm{~h}$ and $24 \mathrm{~h}$ immersion. Electrochemical impedance spectroscopy (EIS) measurements corroborate these results and indicate that the value of polarization resistance increased with DTMD concentration for $1 \mathrm{~h}$ immersion time. Addition of $10^{-2} \mathrm{M}$ DMTD in the test solution exhibited a maximum inhibitive efficiency of $97 \%$ up to $24 \mathrm{~h}$ immersion. Surface analysis techniques were conducted on copper specimens after $24 \mathrm{~h}$ immersion in $0.1 \mathrm{M} \mathrm{NaCl}$ solution. SEM/EDX results confirmed that DMTD forms an adsorbed protective layer on copper surface which was found to be hydrophobic as indicated by contact angle (CA) measurements. These results were further confirmed by XRD patterns which indicated the lack of crystallized corrosion products. $\mathrm{Cl}^{-}$and $\mathrm{Cu}^{2+}$ ions concentrations in the solution, after 30 days immersion of copper sheet in $0.1 \mathrm{M} \mathrm{NaCl}$ solution with and without $10^{-2} \mathrm{M}$ DMTD, were determined by ionic chromatography (IC) and conducted by Inductively Coupled Plasma-Atomic Emission Spectroscopy (ICP-AES) respectively. The results showed that without DMTD $\mathrm{Cl}^{-}$ concentration decreases, while $\mathrm{Cu}^{2+}$ one increases due to corrosion process. In contrast, in the presence of $10^{-2} \mathrm{M}$ DMTD chloride ions concentration remained practically unchanged ( $0.099 \mathrm{~mol} / \mathrm{L})$ and $\mathrm{Cu}^{2+}$ concentration is quite low.
\end{abstract}

Key words: copper, EIS, SEM/EDX, XRD, ICP-AES, IC, neutral inhibition.

Received: April 8, 2019. Published: April 29, 2019

doi: $\underline{10.17675 / 2305-6894-2019-8-2-14}$

\section{Introduction}

Copper and its alloys are highly recommended in several industrial applications, such as pipelines, electrical power lines, electronic industries and communications, water functionalities containing sea water, heat exchangers and conductors [1-7]. The wide range of applications is explained by its outstanding mechanical, electrical, and thermal properties coupled with suitable corrosion resistance [8]. The latter is ensured in several 
chemical conditions and atmospheric environment by forming corrosion products with non conductive behavior or a barrier layer of oxides $[9,10]$. However, corrosion of copper is much more accelerated in some chemical specific environment especially those containing $\mathrm{O}_{2}$, sulfate, chloride and nitrates ions which are known as aggressive anions towards copper [11-18].

It is appropriate to remind that the corrosion of copper based materials takes place through the dissolution of copper in different media, which is generally governed by cathodic and anodic reaction rates [3]. However, corrosion studies are essentially focused on the anodic polarization characteristics, particularly in neutral or nearly neutral $\mathrm{pH}$ condition [19,20]. Thus, many researchers [2,4,5] suggested copper dissolution mechanisms in chloride solutions, which are generally influenced by the $\mathrm{pH}$ value and the concentration of chloride ions in the solution. Dissolution of copper occurs through the formation of weakly protective $\mathrm{CuCl}$ layer at concentrations lower than $1 \mathrm{M}$. This layer might turn into soluble $\mathrm{CuCl}_{2}^{-}$due to interaction with excessive amount of chloride [1]. According to Bacarella et al. [2], electro dissolution of copper and mass transport of soluble $\mathrm{CuCl}_{2}^{-}$, from the Helmholtz plane to the bulk solution, control anodic dissolution of copper. Otherwise, Hoepner et al. indicated the formation of cuprous complexes $\left(\mathrm{CuCl}_{3}^{2-}\right.$ and $\left.\mathrm{CuCl}_{4}^{3-}\right)$ as well as some chloride amount $\left(\mathrm{CuCl}\right.$ and $\left.\mathrm{CuCl}_{2}^{-}\right)$in the case of concentrations higher than $1 \mathrm{M}$ [21].

Copper corrosion and formation of corrosion products on the surface induces an undesirable impact on copper based systems functionalities. This issue has attracted much interest and numerous researches have been conducted up to date in order to find optimal solutions that can minimize the damage arising in corrosive environments [22]. In one hand, many studies were performed in order to investigate the inhibitive efficiency on copper corrosion in different media, especially in chloride ions containing solution. In the other hand, some necessary approaches have been taken into account to protect copper from the damaging effects of corrosion by the use of coatings including corrosion inhibitors [23]. Several works were focused on the inhibitive effect of organic molecules on copper corrosion: many discrepancies about the efficiency of most of those organic inhibitors are found to be leaning on the structural features of the tested inhibitors and the adsorption type which are crucial criterions regarding the inhibitive efficiency [23]. Additionally, the compounds containing hetero-atoms were proved to enable binding with copper substrate. For instance, Antonijovic and Petrovic have recently highlighted the importance of hetero-atoms as nitrogen, sulfur, and phosphorus in organic molecules in order to create good inhibitor candidates [22]. In the same trend, numerous studies investigated the efficiency of inhibitors containing sulfur atoms for copper protection in various media [6,7], due to the strong affinity of sulfur atom towards copper surface [24]. A work dating back to 1960-1975 time period [25,26] was devoted to study copper corrosion inhibition by focusing on benzotriazole and copper interaction. 
Dugdale and Cotton [25] stated that the inhibitory action of BTAH on copper in $\mathrm{NaCl}$ $3 \%$ solution consists of the formation of a physical barrier through surface complex of $\mathrm{Cu}-\mathrm{BTAH}$ [25]. In his turn, Evans [27] claimed that chlorides are involved in the inhibition mechanism and the formation of a protective layer. Other works on copper corrosion inhibition using organic molecules showed that mercaptoimidazole provided a good copper corrosion protection [28]. For instance, 2-mercaptobenzimidazole exhibited an excellent inhibitive effect towards copper corrosion in acidic aerated media, in contrast to benzotriazole which yielded a low inhibitive efficiency [29].

Other relevant inhibitors were used and claimed to be efficient, like PDTC which expressed protective effect as showed in previous works, due to the formation of strongly stable $\mathrm{Cu}-\mathrm{PDTC}$ complex $[30,31]$. On the other hand, thiadiazole derivatives were tested as potential inhibitors due to their non toxicity and eco-friendly features [32]. Moreover, their inhibitive action is mainly influenced by several parameters such as $\mathrm{pH}$ solution, and copper surface condition as reported elsewhere [23]. Among the innoxious thiadiazole derivatives, 2-amino-5-ethylthio-1,3,4-thiadiazole [33], 2-acetamino-5-mercapto-1,3,4thiadiazole [34] and 2-amino-5-mercapto-1,3,4-thiadiazole [22] are candidates. Furthermore, several studies were carried out on other compounds belonging to thiadiazole family, namely dimercaptothiadiazole (DMCT), and exhibited a good efficiency of the dithio compound towards copper corrosion [30, 35].

Few researches were carried out using 1,3,4-thiadiazole-2,5-dithiol (DMTD) to inhibit corrosion of copper. In acidic media, Baeza et al. investigated the inhibition of copper corrosion in $0.5 \mathrm{M} \mathrm{HCl}$ and at $25^{\circ} \mathrm{C}$, using 1,3,4-thiadiazole-2,5-dithiol (bismuthiol), and found that the efficiency increased with inhibitor concentration until it reaches $84.1 \%$ as a maximum value at $80 \cdot 10^{-5} \mathrm{M}$. The inhibitive effect, due the formation of complexes, was assessed by chemisorption and followed Langmuir isotherm [36].

In a similar way, DMTD was tested as a self assembled monolayer (SAM) to inhibit copper corrosion in acidic environment by Qin et al. [37]. The authors showed that DMTD adsorption on copper surface was ensured by its three sulfur atoms in typically parallel manner which gave arise to the presence of a hydrophilic film [37].

Moreover, in neutral media, Yadav et al. [24] studied the influence of DMTD on copper corrosion in $3.5 \% \mathrm{NaCl}$ solution and claimed that DMTD presents a significant inhibitive effect insured by with the formation of a protective layer. The latter was formed by $\mathrm{Cu}(\mathrm{I})-\mathrm{DMTD}$ complex, cuprous chloride, $\mathrm{CuCl}$ or $\mathrm{Cu} \mathrm{Cl}_{2}^{-}$complex ion or both, while there was absence of oxide form on the studied copper surface.

In previous work, inhibition of copper corrosion by DMTD was studied in neutral $0.2 \mathrm{M} \mathrm{NaCl}$ solution. The results showed that DMTD inhibited both anodic dissolution of copper and oxygen reduction reaction (ORR) by the formation of a protective film. Under open circuit conditions, the synergetic effect of a 1:1 mixture of DMTD and PDTC (1pyrrolidine-dithiocarbamate) was also studied in neutral $\mathrm{NaCl}$ medium. The results indicated that the combination of the two inhibitors resulted in a synergetic inhibition of 
both anodic and cathodic reactions. The mixture of both compounds lead to the formation of an irreversible protective coating as indicated by their anodic electro-activity [38].

In the present work, the investigation of the inhibitive effect of DMTD on copper corrosion in $0.1 \mathrm{M} \mathrm{NaCl}$ media is studied by means of electrochemical techniques. To understand the interactions between DMTD and copper surface, SEM/EDX, XRD analysis and Contact angle (CA) measurements were used. Moreover, the solution analysis is conducted by Inductively Coupled Plasma-Atomic Emission Spectroscopy (ICP-AES) and Ion chromatography (IC).

\section{Experimental}

\subsection{Chemicals and materials}

The working electrode consisted of a copper disk prepared from a pure copper cylinder rod (Goodfellow, 99.999\% of purity) of $5 \mathrm{~mm}$ in diameter. Specimens were mounted in Teflon cylinder and the space between the copper electrode and Teflon wall was filled by an epoxy resin. Before starting the experiments, the electrode surface was abraded using emery SiC paper (up to 1200), and rinsed throughouly using distilled water. The electrode was approached to the centre of the cell under stationary conditions without stirring. A saturated $\mathrm{KCl}$ calomel electrode was used as reference, while the counter electrode was a platinum one, separated from the working electrode compartment by fritted glass.

A copper sheet, with dimensions of $1 \times 1 \times 0.2 \mathrm{~cm}^{3}$ provided from Goodfellow $(99.999 \%)$, was used for surface and solution analysis.

The corrosive solution was prepared using analytical reagent grade chemicals $(\mathrm{NaCl}$, Fluka, 99.5\%) and bidistilled water in order to obtain $0.1 \mathrm{M} \mathrm{NaCl}$ solution as a blank solution.

$10^{-2} \mathrm{M}$ of DMTD $\left(\mathrm{C}_{2} \mathrm{H}_{2} \mathrm{~N}_{2} \mathrm{~S}_{3}, \mathrm{M}=150.23 \mathrm{~g} / \mathrm{mol}\right.$, provided by Aldrich $\left.{ }^{\circledR}\right)$ was added directly as inhibitor to the blank solution. Further dilutions were performed in order to prepare a series of solutions with different concentrations namely $10^{-3} \mathrm{M}, 10^{-4} \mathrm{M}$ and $10^{-5} \mathrm{M}$. Note that, $50 \mathrm{~mL}$ of the prepared solution was used for each experiment. All tests were carried out at ambient temperature. The molecular structure of DMTD is given in Figure 1.This molecule has five hetero-atoms: two nitrogen and three sulfur atoms.

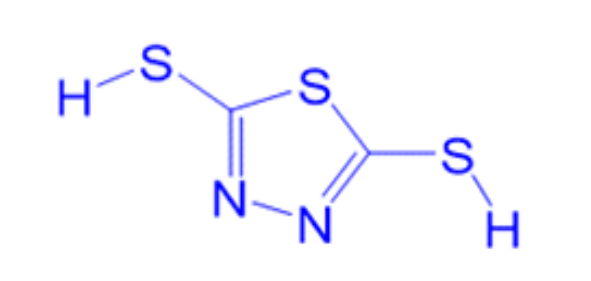

Figure 1. Molecular structure of 1,3,4 -thiadiazole-2,5-dithiol. 


\subsection{Electrochemical measurements}

Electrochemical tests were performed in a conventional three-electrode cell, using Voltalab 40 (Tacussel-Radiometer PGZ301) potentiostat and controlled by Tacussel corrosion analysis software model (Voltamaster 4). The electrochemical tests were started by measuring the Open Circuit Potential $E_{\mathrm{OCP}}$ of the electrode, until the steady state conditions were reached on the electrode surface. The $E_{\mathrm{OCP}}$ measured was considered as the corrosion potential $\left(E_{\text {corr }}\right)$. Before electrochemical measurements, copper electrode was immersed during $1 \mathrm{~h}$ or $24 \mathrm{~h}$ in the solution at open circuit potential.

\subsubsection{Potentiodynamic polarization}

Polarization curves were drawn from two independent measurements in a freshly prepared test solution for each run: the first measurement is the cathodic one which was undertaken from $E_{\text {corr }}$ towards $-1.5 \mathrm{~V}$, the second one was performed from $E_{\text {corr }}$ to $+1.5 \mathrm{~V}$ [38] at a potential scan rate of $10 \mathrm{mV} / \mathrm{s}$ [31]. The polarization curves were plotted for each part, after $1 \mathrm{~h}$ or $24 \mathrm{~h}$ immersion of the electrode in the tested solutions.

\subsubsection{EIS measurements}

EIS diagrams were plotted in $100 \mathrm{kHz}-10 \mathrm{mHz}$ frequency range with 10 points per decade and a $10 \mathrm{mV}$ amplitude of the excitation signal. Experimental data were obtained after $1 \mathrm{~h}$ and $24 \mathrm{~h}$ immersion at $E_{\text {corr }}$. The EIS results were explained using equivalent electrical circuits (EEC). The fitting and analysis of the measured data were performed using ECLab program.

\subsection{Surface analyses}

\subsection{1. $X$-ray diffraction $(X R D)$}

The surface layers formed, with and without $10^{-2} \mathrm{M}$ DMTD within $24 \mathrm{~h}$ immersion, were analyzed using X-RAY diffraction (Semiens D5000) with $\mathrm{Cu} \mathrm{K \alpha}$ radiation $(\lambda=1.54056 \AA$ ). In order to identify the crystalline phases, a scanning range 10-80 with 0.04 step was used and was recorded each 5 seconds.

\subsubsection{SEM/EDX}

The SEM micrographs were picked up after $24 \mathrm{~h}$ immersion time in $0.1 \mathrm{M} \mathrm{NaCl}$ without and with $10^{-2} \mathrm{M}$ DMTD using FEI Quanta FEG 450 scanning electronic microscope (SEM). Bruker EDX analyzer was used with accelerating voltage of $20 \mathrm{kV}$ to evidence the formed layers on copper surface in the absence and presence of DMTD.

\subsubsection{Contact Angle experiments}

The wettability of the inhibited and uninhibited copper surfaces immersed during $24 \mathrm{~h}$ in the tested solutions, were investigated via measurement of the contact angle by placing a 
water droplet in contact with the surface using a micrometer syringe. In order to measure the contact angle, a camera was used to scan the droplet profile. Furthermore, to avoid the effect of weight, the drop size of the distilled water was about $3 \mu \mathrm{L}$.

\subsection{Solution analyses}

\subsubsection{Inductively Coupled Plasma-Atomic Emission Spectroscopy (ICP-AES)}

The concentration of $\mathrm{Cu}^{2+}$ ions, after 30 days immersion of the copper sheet, in the solution test with or without DMTD was evaluated by means of ICP-AES, HORIBA model Activa M.

\subsubsection{Ion chromatography (IC)}

Analysis of the solution using ion chromatography was conducted to assess $\mathrm{Cl}^{-}$ions concentration after during 30 days immersion of copper electrode in $0.1 \mathrm{M} \mathrm{NaCl}$ without and with $10^{-2}$ M DMTD. The analysis was carried out using ion chromatography DIONEX ICS3000 equipped with a capillary column AS19 Analytical column + AG19 Guard column (size $4 \times 250 \mathrm{~mm}$ ). The pressure was estimated as $15.16 \mathrm{MPa}$ and the flow rate was set as $1 \mathrm{~mL} / \mathrm{min}$ at room temperature. To reduce the concentration of chloride ions, the samples were diluted with ultra pure water then injected by a syringe equipped with a filter of $0.45 \mu \mathrm{m}$.

\section{Results and discussion}

\subsection{Electrochemical measurements}

\subsubsection{Potentiodynamic polarization}

Anodic and cathodic curves were plotted starting from $E_{\text {corr }}$ during two independent experiments at different DMTD concentrations, after $1 \mathrm{~h}$ immersion of the electrode in the tested solutions. The obtained curves are gathered in Figure 2. In the blank test solution, an increase of the anodic current density is observed with no appearance of any peak. Furthermore, no region of passivity appears in the $\mathrm{NaCl}$ solution as reported in previous works conducted on pure copper in diluted $\mathrm{NaCl}$ solution $[3,39,40]$. This is probably due to the absence or minimal amount of formed $\mathrm{CuCl}$ [31]. The cathodic process entails the appearance of two current peaks one around $-365 \mathrm{mV}$ and another at $-990 \mathrm{mV}$. They may correspond to $\mathrm{Cu}_{2} \mathrm{O}$ and $\mathrm{CuCl}$ reduction respectively. Besides, oxygen reduction reaction can be guessed in the potential region going from $-500 \mathrm{mV}$ to $-800 \mathrm{mV}$. This is in good accordance with previous studies on the electrochemical behavior of pure copper in $0.2 \mathrm{~g} / \mathrm{L}$ $\mathrm{NaCl}$ solution [41].

Effect of DMTD addition for both cathodic and anodic scans, is investigated as shown in Figure 2 and indicates that the increase of DMTD concentration lowered the corrosion current density in the whole potential domain. This result was assessed elsewhere [42]. 
Note that for all concentrations of DMTD, $E_{\text {corr }}$ values are slightly more anodic than the one obtained for the blank test solution.

As it can be seen in Figure 2, a sharp decrease of current density is obtained after the addition of $10^{-2} \mathrm{M}$ DMTD in the test solution, which was chosen as optimal inhibitor concentration. For $10^{-2} \mathrm{M}$ DMTD, the cathodic behavior is characterized by the disappearance of $\mathrm{Cu}_{2} \mathrm{O}$ reduction peak, as well as the disappearance of the pseudo-plateau related to $\mathrm{O}_{2}$ reduction. Whereas, the corresponding $\mathrm{CuCl}$ reduction peak is shifted from $-990 \mathrm{mV}$ to $-700 \mathrm{mV}$.

In the anodic part, the presence of $10^{-2} \mathrm{M}$ DMTD results in an emergence of small peak at about $317 \mathrm{mV}$. Similar behavior was observed in previous work while studying the effect of PDTC on the inhibition of copper corrosion in $0.2 \mathrm{~g} / \mathrm{L} \mathrm{NaCl} \mathrm{[41].} \mathrm{The} \mathrm{observed} \mathrm{peak} \mathrm{was}$ then attributed to electrosorption process generating $\mathrm{Cu}$-PDTC surface layer [41]. Consequently, the emerged peak followed by a broad current plateau is more likely due to the adsorption of DMTD molecules, which indicates a very strong anodic inhibition [41].

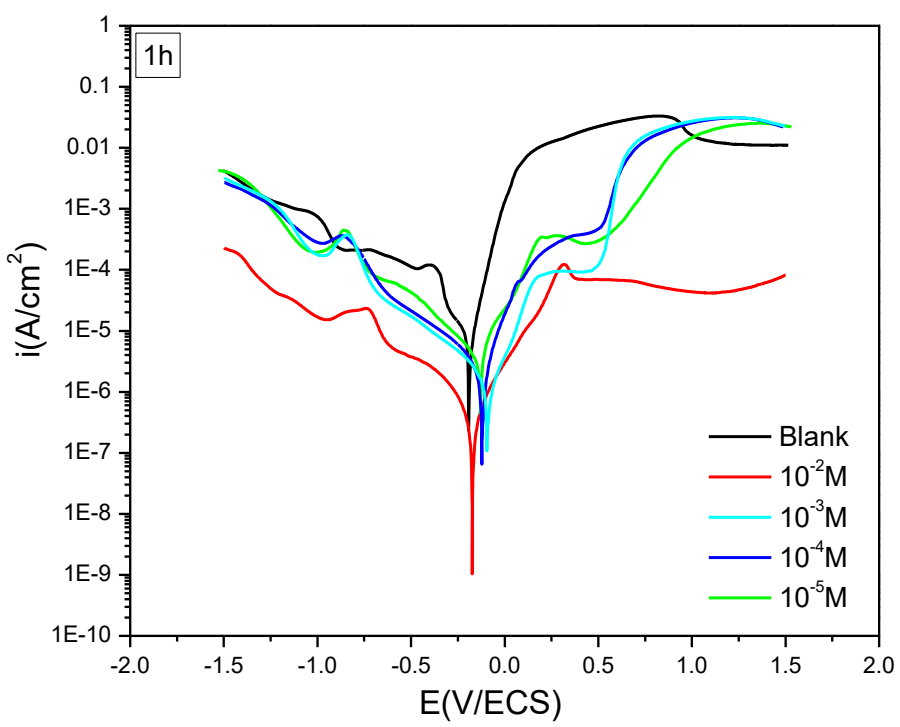

Figure 2. Effect of different concentrations of DMTD on copper polarization curves after 1 hour immersion in $0.1 \mathrm{M} \mathrm{NaCl}$ solution.

Figure 3 shows the polarization curves obtained after $1 \mathrm{~h}$ and $24 \mathrm{~h}$ of copper electrode immersion in $0.1 \mathrm{M} \mathrm{NaCl}$ with and without $10^{-2} \mathrm{M}$ DMTD. Long immersion time was chosen in order to get further information about the influence of $\mathrm{NaCl}$ and DMTD on the corrosion behavior of copper and its inhibition.

Without DMTD (Figure 3a) and after $24 \mathrm{~h}$ immersion, the cathodic part is characterized by a peak attributed to $\mathrm{Cu}_{2} \mathrm{O}$ reduction which is slightly shifted towards negative potential $(-406 \mathrm{mV})$ in comparison with that obtained for $1 \mathrm{~h}$. The same behavior is observed for a second peak $(-1100 \mathrm{mV}$ after $24 \mathrm{~h})$, corresponding to $\mathrm{CuCl}$ reduction, 
since it is about $110 \mathrm{mV}$ more cathodic than the one obtained after $1 \mathrm{~h} \mathrm{immersion}$. It is worthy to mention that $\mathrm{O}_{2}$ reduction plateau is extended between $-500 \mathrm{mV}$ and $-850 \mathrm{mV}$. Note that the cathodic current densities of the peaks observed after $24 \mathrm{~h}$ immersion in the test solution are greater than the ones obtained for $1 \mathrm{~h}$. Conversely, the anodic part of the curve recorded after $24 \mathrm{~h}$ immersion time is practically similar to that corresponding to $1 \mathrm{~h}$.
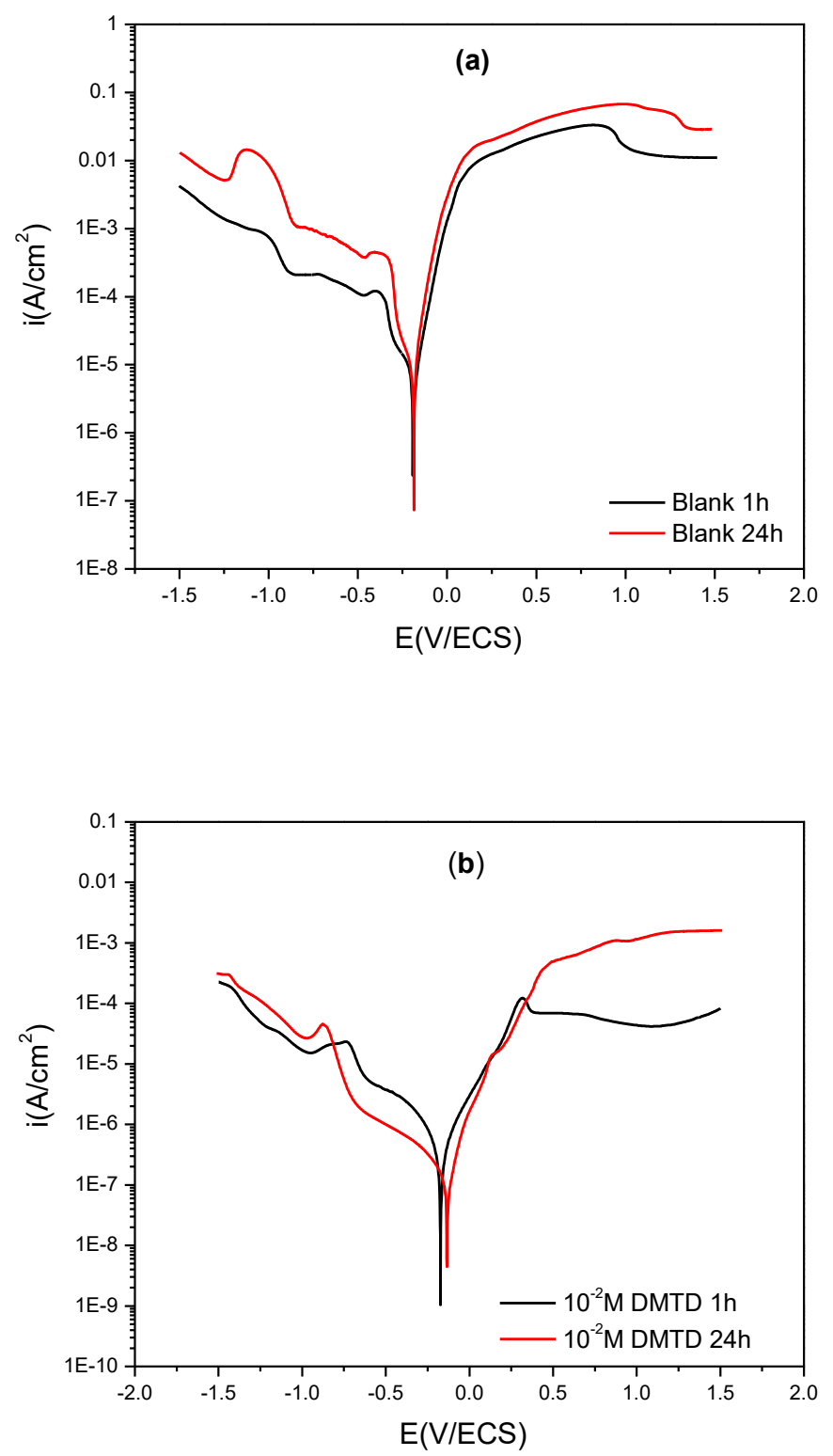

Figure 3. Polarization curves of copper after $1 \mathrm{~h}$ and $24 \mathrm{~h}$ immersion in the absence (a) and the presence of $10^{-2} \mathrm{M}$ DMTD (b) in $0.1 \mathrm{M} \mathrm{NaCl}$ solution.

In the presence of $10^{-2} \mathrm{M}$ DMTD (Figure $3 \mathrm{~b}$ ) the shape of both anodic and cathodic branches after $24 \mathrm{~h}$ immersion is similar to the one obtained after $1 \mathrm{~h}$ immersion. However, analysis of the polarization curves shows that $\mathrm{CuCl}$ reduction peak is displaced towards 
more cathodic potentials and exhibits a value of $-867 \mathrm{mV}$ after $24 \mathrm{~h}$ immersion (a difference of $167 \mathrm{mV}$ if compared to $1 \mathrm{~h}$ ). Moreover, it can be noticed that the cathodic current densities are lower after $24 \mathrm{~h}$ immersion, probably due to the formation of a film onto copper surface which slows down oxygen reduction reaction kinetics [30].

Moreover, the comparison of the polarization curves obtained with and without $10^{-2} \mathrm{M}$ DMTD after $24 \mathrm{~h}$ immersion, shows a drastic decrease in current density particularly around $E_{\text {corr }}$. This behavior is practically similar to the results obtained in previous studies $[30,41]$. In the anodic region the curve exhibits a feature similar to a limiting current region in largely extended potential range. This is more likely originated from the adsorption of DMTD which hinders the electron transfer at the electrode surface. This enables the production of only few amount of $\mathrm{CuCl}_{2}$ at the electrode surface [43]. In the cathodic region, it is noticeable that in the presence of DMTD in the solution, the peak corresponding to $\mathrm{Cu}_{2} \mathrm{O}$ reduction located at $-406 \mathrm{mV}$ disappears after $24 \mathrm{~h}$ immersion time.

From these results, it can be concluded that DMTD disables the formation of oxides for both immersion times. This fact was more clarified in previous work where no $\mathrm{Cu}_{2} \mathrm{O}$ reduction peak appeared in the $30 \mathrm{~g} / \mathrm{L} \mathrm{NaCl}$ solution containing $10^{-2} \mathrm{M}$ PDTC. This was explained by the readily PDTC adsorption inhibiting oxide formation [31].

Table 1 summarizes the electrochemical parameters determined from polarization curves of copper in $0.1 \mathrm{M} \mathrm{NaCl}$ solution without and with DMTD. The values of corrosion current densities were determined using Tafel extrapolation method [44]. Inhibition efficiency values $I E(\%)$ was calculated as follows:

$$
I E(\%)=\frac{I_{\text {corr }}^{0}-I_{\text {corr }}}{I_{\text {corr }}^{0}} \times 100
$$

where $i_{\text {corr }}^{0}$ stands for the corrosion current density extracted in the blank test solution while $i_{\text {corr }}$ denotes the corrosion current measured in the presence of DMTD.

By examining the parameters presented in Table 1, it is noticeable that the presence of DMTD leads to significant decrease of corrosion current densities for both immersion times, though $24 \mathrm{~h}$ presents important inhibitive efficiency. Hence, DMTD acts as mixed type inhibitor. The same behavior has been evidenced elsewhere [42].

\subsubsection{EIS measurements}

\section{a. After 1 hour immersion}

Nyquist and Bode diagrams of copper electrode, recorded after 1 hour immersion, in $0.1 \mathrm{M}$ $\mathrm{NaCl}$ solution without and with different DMTD concentrations, are depicted in Figures 4 and 5 respectively. 
Table 1. Corrosion parameters obtained from polarization curves of copper in $0.1 \mathrm{M} \mathrm{NaCl}$ without and with DMTD.

\begin{tabular}{|c|c|c|c|c|c|c|}
\hline $\begin{array}{c}\text { Immersion } \\
\text { time }\end{array}$ & $C$ & 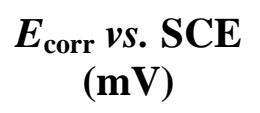 & $\begin{array}{c}I_{\text {corr }} \\
\left(\mu \mathrm{A} / \mathbf{c m}^{2}\right)\end{array}$ & $\begin{array}{c}\boldsymbol{\beta}_{\mathrm{a}} \\
\text { (mV/dec) }\end{array}$ & $\begin{array}{c}-\boldsymbol{\beta}_{\mathbf{c}} \\
\text { (mV/dec) }\end{array}$ & $I E(\%)$ \\
\hline \multirow{5}{*}{$1 \mathrm{~h}$} & $0.1 \mathrm{M} \mathrm{NaCl}$ & -189 & 2.76 & 65 & 37 & - \\
\hline & $\begin{array}{c}0.1 \mathrm{M} \mathrm{NaCl}+ \\
10^{-5} \mathrm{M} \mathrm{DMTD}\end{array}$ & -85 & 0.35 & 69 & 51 & 87 \\
\hline & $\begin{array}{l}0.1 \mathrm{M} \mathrm{NaCl}+ \\
10^{-4} \mathrm{MDMTD}\end{array}$ & -112 & 0.28 & 73 & 28 & 89 \\
\hline & $\begin{array}{l}0.1 \mathrm{M} \mathrm{NaCl}+ \\
10^{-3} \mathrm{MDMTD}\end{array}$ & -131 & 0.25 & 81 & 45 & 90 \\
\hline & $\begin{array}{l}0.1 \mathrm{M} \mathrm{NaCl}+ \\
10^{-2} \mathrm{MDMTD}\end{array}$ & -170 & 0.15 & 87 & 41 & 94 \\
\hline \multirow[b]{2}{*}{$24 \mathrm{~h}$} & $0.1 \mathrm{M} \mathrm{NaCl}$ & -190 & 3 & 60 & 56 & - \\
\hline & $\begin{array}{l}0.1 \mathrm{M} \mathrm{NaCl}+ \\
10^{-2} \mathrm{MDMTD}\end{array}$ & -121 & 0.08 & 101 & 47 & 95 \\
\hline
\end{tabular}

In the blank solution, a single semi-circle showing a depressed feature is observed at high and middle frequency range. At low frequency range, the semicircle is followed by a straight line, inclining at $45^{\circ}$ angle with the horizontal axis and corresponds to Warburg impedance attributed to the diffusion of corrosion products [45].

Bode plots present two time constants appearing subsequently. For high and middle frequency domain, the time constant observed corresponds to a badly separated capacitances related to the dielectric nature of the surface film as well as charge transfer and double layer capacitance at the electronic and ionic conducting interface as obtained in previous work [31]. At low frequency domain the second time constant is ascribed to the diffusion phenomenon [42].

In the presence of DMTD, Warburg behavior observed at low frequency range in the blank solution disappears which indicates that charge transfer process controls copper corrosion inhibition [46]. Furthermore, it can be noticed that the increase of DMTD concentration induces the increase in loops diameter in Nyquist plots (Figure 4) suggesting that the inhibition efficiency is improved with the increase of DMTD concentration $[47,48]$. Consequently, it can be assumed that DMTD is a good inhibitor for copper corrosion.

Comparison of the results obtained without and with DMTD suggests the formation of a protective film on copper surface as evidenced by the phase angle increase [49]. In the whole frequency domain, the value of impedance modulus increases as well, which proves the enhancement of protective ability as DMTD concentration increases [47]. This evolution can be related to the adsorption of DMTD molecules on the studied surface. Note 
that the same behavior was found by Zaklina et al. [50] investigations on copper inhibition by cephradine inhibitor in $0.9 \% \mathrm{NaCl}$.

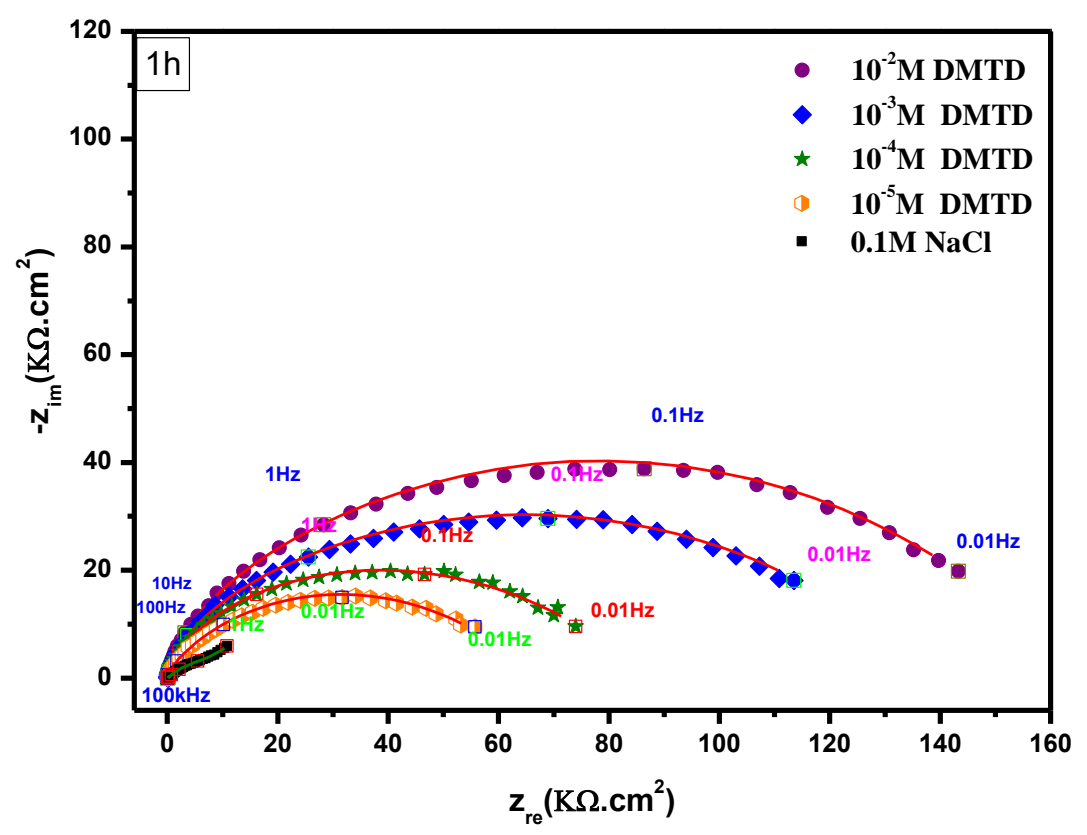

Figure 4. Nyquist diagrams of copper electrode in the absence and presence of DMTD at various concentrations in $0.1 \mathrm{M} \mathrm{NaCl}$ after 1 hour immersion. Symbols designate experimental data and solid lines fitted data.

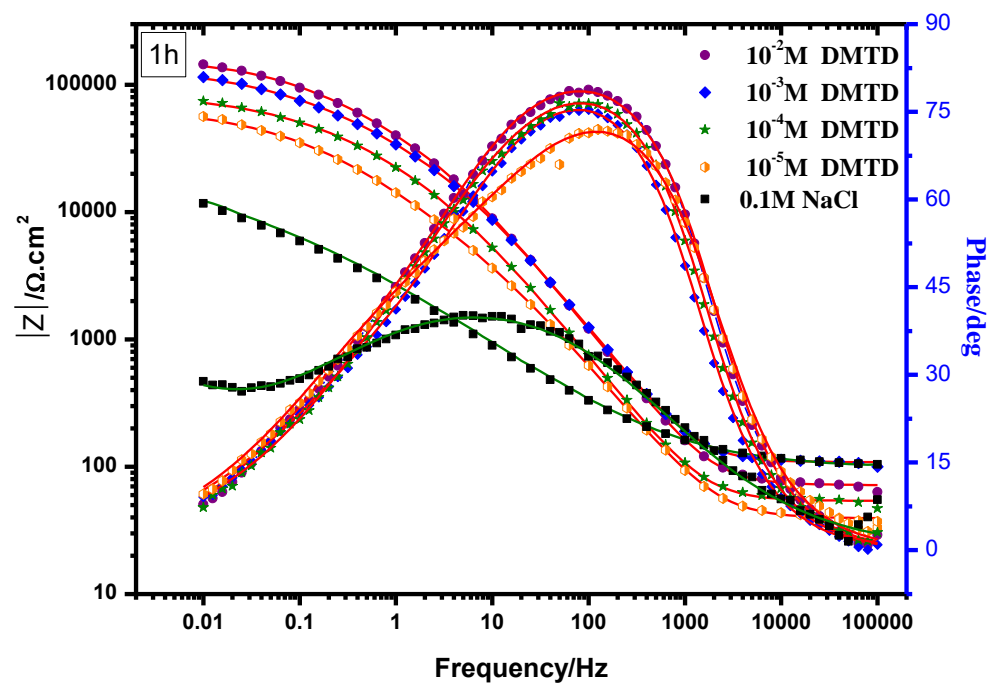

Figure 5. Bode diagrams of copper electrode in $0.1 \mathrm{M} \mathrm{NaCl}$ without and with various DMTD concentrations. Symbols designate experimental data and solid lines fitted data. 
Figure 6 illustrates the equivalent circuit models used to fit the EIS experimental data obtained without and with DMTD in $\mathrm{NaCl}$ solution. The deduced parameters are gathered in Table 2.

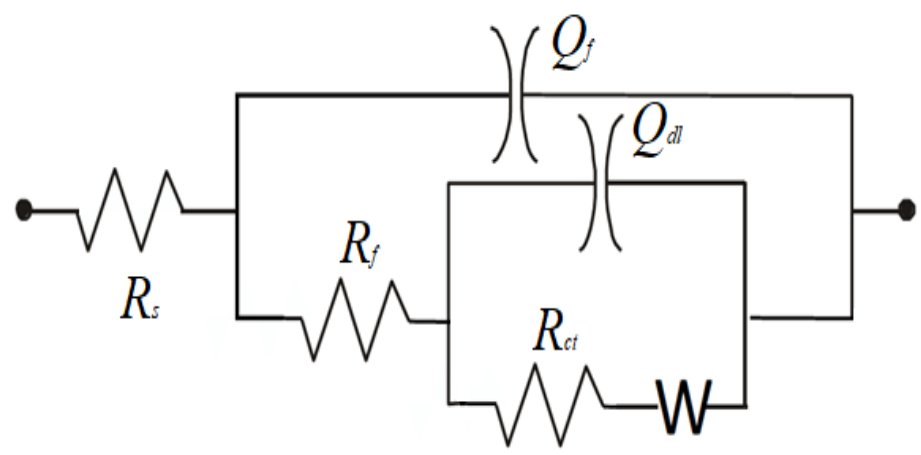

Figure 6. Equivalent circuit used to fit the impedance plots for copper in $0.1 \mathrm{M} \mathrm{NaCl}$ without and with DMTD after $1 \mathrm{~h}$ and $24 \mathrm{~h}$ immersion [47, 50].

Table 2. Electrochemical parameters determined from EIS diagrams obtained on copper surface after $1 \mathrm{~h}$ immersion in $0.1 \mathrm{M} \mathrm{NaCl}$ without and with DMTD at various concentrations.

\begin{tabular}{|c|c|c|c|c|c|c|c|c|c|c|c|}
\hline$\underset{\mathrm{mol} / \mathrm{L}}{C_{\mathrm{inh}}}$ & $\begin{array}{c}R_{\mathrm{s}} \\
\Omega \mathrm{cm}^{2}\end{array}$ & $\begin{array}{c}\boldsymbol{R}_{\mathrm{ct}} \\
\mathbf{k} \boldsymbol{\Omega} \mathbf{c m}^{2}\end{array}$ & $n_{\mathrm{dl}}$ & $\underset{\mu \mathrm{F} / \mathbf{c m}^{2}}{C_{\mathrm{dl}}}$ & $\begin{array}{c}R_{\mathrm{f}} \\
\mathbf{k} \boldsymbol{\Omega} \mathbf{~ c m}^{2}\end{array}$ & $n_{\mathrm{f}}$ & $\begin{array}{c}C_{\mathrm{f}} \\
\mu \mathrm{F} / \mathbf{c m}^{2}\end{array}$ & $\underset{\mathrm{nm}}{d}$ & $\begin{array}{c}R_{\mathbf{p}} \\
\mathbf{k} \boldsymbol{\Omega} \mathbf{~ c m}^{2}\end{array}$ & $\begin{array}{c}W \\
\Omega^{-1} \mathrm{~cm}^{-2} \mathbf{s}^{0.5}\end{array}$ & $\begin{array}{l}E_{\text {SIE }} \\
(\%)\end{array}$ \\
\hline Blank & 99.48 & 10.983 & 0.523 & 184.681 & 0.100 & 0.300 & 9.560 & 0.7 & 11.983 & 1387 & - \\
\hline $10^{-5}$ & 39.22 & 62.517 & 0.506 & 25.832 & 4.145 & 0.897 & 3.075 & 2.158 & 66.663 & - & 83 \\
\hline $10^{-4}$ & 53.94 & 78.299 & 0.479 & 15.293 & 8.790 & 0.933 & 2.545 & 2.608 & 87.090 & - & 87 \\
\hline $10^{-3}$ & 108.46 & 123.718 & 0.488 & 14.441 & 15.672 & 0.929 & 1.546 & 4.293 & 139.390 & - & 92 \\
\hline $10^{-2}$ & 71.73 & 141.268 & 0.535 & 10.152 & 23.837 & 0.937 & 1.543 & 4.301 & 165.105 & - & 93 \\
\hline
\end{tabular}

$R_{\mathrm{s}}$ stands for the electrolyte resistance between the reference electrode and copper, $R_{\mathrm{f}}$ is the film resistance formed on copper surface, $Q_{\mathrm{f}}$ represents the constant phase elements (CPE) constituted of $C_{\mathrm{f}}$ capacitance and $n_{\mathrm{f}}$ as deviation parameter, $R_{\mathrm{ct}}$ is the resistance of charge transfer process attributed to the corrosion process at the metal substrate/electrolyte interface, $Q_{\mathrm{dl}}$ accounts for the CPE containing the double-layer capacitance $C_{\mathrm{dl}}$ and $n_{\mathrm{dl}}$. $W$ represents the Warburg diffusion impedance element.

As stated above, no diffusion behavior is noticed in the presence of DMTD. Therefore, Warburg impedance was blocked while adjusting the electrochemical results.

The constant phase elements (CPE) replace the capacitive elements in the electrical equivalent circuit (Figure 6). Generally, the CPE accounts for deviations related to depression of the capacitive loops. The impedance of the $\mathrm{CPE}\left(Z_{\mathrm{CPE}}\right)$ is expressed as [51]:

$$
Z_{\mathrm{CPE}}=\frac{1}{Q(j \omega)^{\mathrm{n}}}
$$


where $-1 \leq n \leq 1, j^{2}=-1, \omega=2 \pi \mathrm{f}$ and $Q$ is a frequency-independent constant defined as pure capacitance for $n=1$, resistance for $n=0$, inductance for $n=-1$. Diffusion processes are characterized by the value of $n=0.5$.

The film thickness $d$ was estimated using the planar condenser model, given by the following equation:

$$
d=\frac{\varepsilon \varepsilon_{0}}{C_{\mathrm{f}}}
$$

where $\varepsilon$ and $\varepsilon_{0}$ stand respectively for the relative dielectric constant and the dielectric constant of vacuum. The value of $\varepsilon$ was considered to be equal to $7.5[30,52]$.

Equations 4 and 5 given below are used to calculate $C_{\mathrm{f}}$ and $C_{\mathrm{dl}}$ values respectively [53]:

$$
\begin{gathered}
C_{\mathrm{f}}=\left(Q_{\mathrm{f}} R_{\mathrm{f}}^{1-n}\right)^{\frac{1}{n}} \\
C_{\mathrm{dl}}=\left(Q_{\mathrm{dl}} R_{\mathrm{ct}}^{1-n}\right)^{\frac{1}{n}}
\end{gathered}
$$

From the values gathered in Table 2, the addition of DMTD in the solution containing $\mathrm{NaCl}$ lowers the values of $\mathrm{C}_{\mathrm{f}}$ and $\mathrm{C}_{\mathrm{dl}}$, whereas the values of $R_{\mathrm{ct}}$ and $R_{\mathrm{f}}$ increase if compared to the blank test solution [50].

The lowering of $C_{\mathrm{f}}$ values is related to the adsorption of DMTD molecules [54] giving arise to the film thickness growth [30]. Moreover, the decrease of $C_{\mathrm{dl}}$ values with the increase of DMTD concentration is obviously related to the thickness increase of electrical double layer coupled with the local dielectric constant decrease. This can be induced by the adsorption of DMTD molecules [55] and formation of a protective layer. The adsorption of DMTD molecules decreases the available active sites number on copper surface, translated consequently by the increase in $R_{c t}$ values with DMTD concentration [50]. Similar results were evidenced in previous work dedicated to investigate copper corrosion inhibition by PDTC in $0.5 \mathrm{~mol} / \mathrm{L}$ and in $0.2 \mathrm{~g} / \mathrm{L}$. It was suggested that electron transfer process and the transport of chloride anions were disabled [31]. The increase of $R_{\mathrm{f}}$ with DMTD concentration is likely caused by the formation of a barrier film and/or corrosion products on copper surface, minimizing the probabilities of reactions between chloride anions and copper [56,57]. As a result, the adsorbed film effectively inhibits the electron transfer process of the dissolution reaction of copper in $0.1 \mathrm{M} \mathrm{NaCl}$.

By examining Table 2, it can be noticed that $n_{\mathrm{f}}$ value increases in the presence of DMTD leading to an obvious lowering of the surface inhomogeneity due to DMTD adsorption.

$n_{\mathrm{f}}$ values vary in the range of $0.89-0.93$ indicating the partial heterogeneity of the adsorbed DMTD film. Besides, the difference in $n_{\mathrm{f}}$ values indicates that the chemical composition of the adsorbed film is modified accordingly with its thickness as indicated by the $R_{\mathrm{f}}$ values [58]. It is worthy to mention that the efficiency is determined as: 


$$
I E(\%)=\frac{R_{\mathrm{p}}^{\mathrm{inh}}-R_{\mathrm{p}}^{0}}{R_{\mathrm{p}}^{\text {inh }}} \times 100
$$

where $R_{\mathrm{p}}^{\mathrm{inh}}$ stands for polarization resistance measured in solution containing DMTD and $R_{\mathrm{p}}^{0}$ denotes for the polarization resistance of the inhibitor free solution.

The inhibition efficiency ( $I E \%$ ) obtained from $R_{\mathrm{p}}$ also increases with the increase of DMTD concentration and is consistent with the one calculated using potentiodynamic polarization measurements.

\section{b. After 24 hours immersion}

EIS measurements are performed after $24 \mathrm{~h}$ immersion of copper electrode in the blank test solution without and with $10^{-2}$ M DMTD. Figures 7 and 8 illustrate the Nyquist and Bode plots respectively.

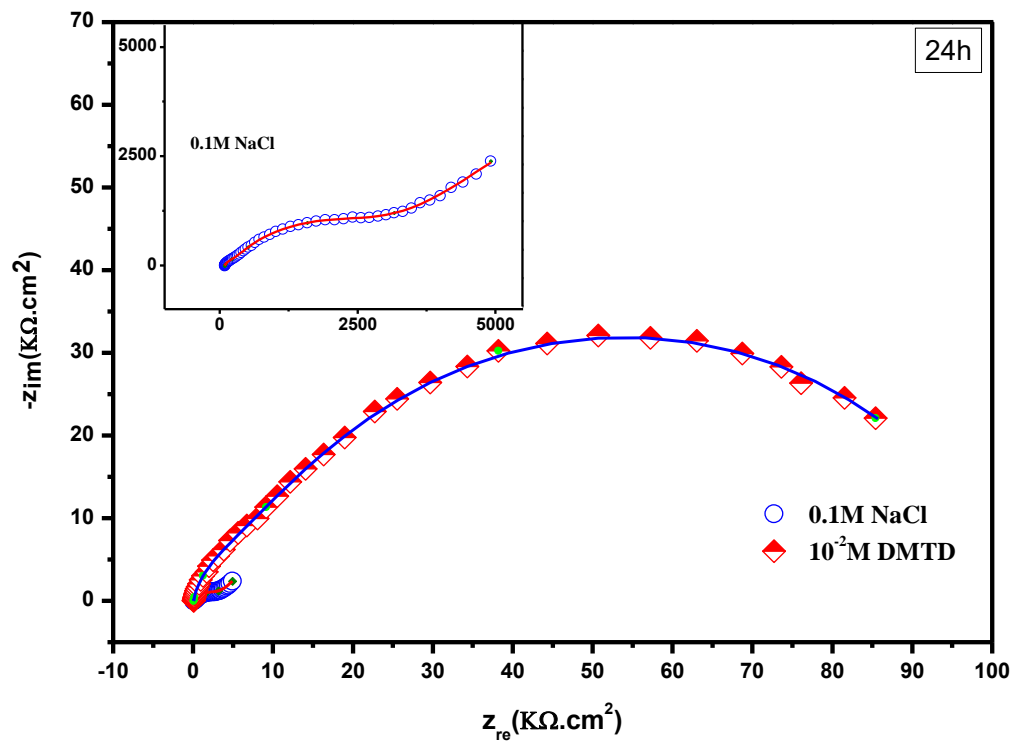

Figure 7. Nyquist diagrams of copper electrode after $24 \mathrm{~h}$ immersion in $0.1 \mathrm{M} \mathrm{NaCl}$ without and with $10^{-2} \mathrm{M}$ DMTD.

Nyquist diagrams (Figure 7) obtained in the blank solution shows a depressed loop, in the high frequency domain, indicating that copper surface is rough and inhomogenous [59]. Moreover, a straight line appears in the low frequency range, which can be attributed to the soluble species diffusion from copper surface into the bulk of the electrolyte [45]. The electrical equivalent circuit [50] proposed to fit accurately the EIS data obtained after $24 \mathrm{~h}$ immersion of the electrode surface in the absence and presence of $10^{-2} \mathrm{M}$ DMTD is similar to the one used to adjust EIS data after $1 \mathrm{~h}$ immersion (Figure 6). The extracted electrochemical parameters obtained after $24 \mathrm{~h}$ immersion are compiled in Table 3. These parameters characterize the presence of three time constants in Bode diagram (Figure 8). 
The Nyquist presentations in Figure 7 clearly show that the loops diameter of the diagram performed in presence of $10^{-2}$ M DMTD at $24 \mathrm{~h}$ immersion is significantly higher than the one obtained for the blank.

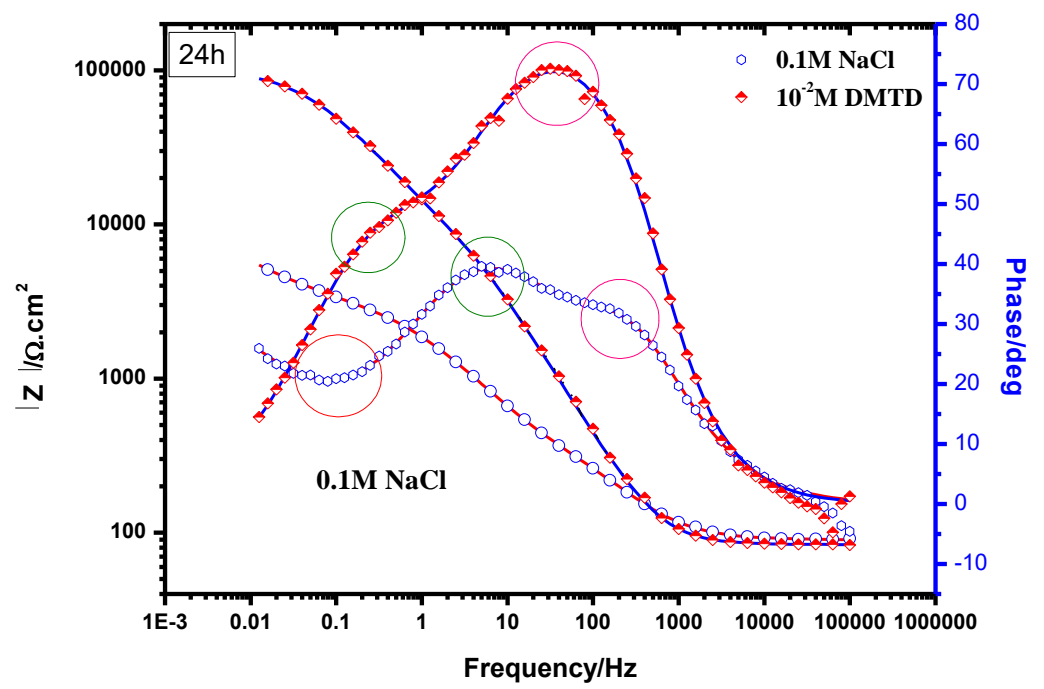

Figure 8. Bode diagrams of copper electrode after $24 \mathrm{~h}$ immersion in $0.1 \mathrm{M} \mathrm{NaCl}$ without and with $10^{-2}$ M DMTD.

Bode plots after $24 \mathrm{~h}$ immersion in the presence of $10^{-2} \mathrm{M}$ DMTD reveals two phase angle plots, related to two different maximums of phase, suggesting the presence of two distinct time constants [50].

Table 3. The extracted electrochemical parameters from EIS data obtained after $24 \mathrm{~h}$ immersion of copper electrode in $0.1 \mathrm{M} \mathrm{NaCl}$ without and without $10^{-2} \mathrm{M}$ DMTD.

\begin{tabular}{|c|c|c|c|c|c|c|c|c|c|c|c|}
\hline$\underset{\mathrm{mol} / \mathrm{L}}{C_{\mathrm{inh}}}$ & $\begin{array}{c}R_{\mathrm{s}} \\
\Omega \mathrm{cm}^{2}\end{array}$ & $\underset{\mathbf{k} \Omega \mathbf{c m}^{2}}{R_{\mathrm{ct}}}$ & $n_{\mathrm{dl}}$ & $\underset{\mu \mathrm{F} / \mathbf{c m}^{2}}{C_{\mathrm{dl}}}$ & $\begin{array}{c}R_{\mathrm{f}} \\
\mathbf{k} \boldsymbol{\Omega} \mathbf{c m}^{2}\end{array}$ & $n_{\mathrm{f}}$ & $\underset{\mu \mathrm{F} / \mathbf{c m}^{2}}{C_{\mathrm{f}}}$ & $\underset{\mathrm{nm}}{d}$ & $\begin{array}{c}R_{\mathbf{p}} \\
\mathbf{k} \Omega \mathbf{c m}^{2}\end{array}$ & $\begin{array}{c}W \\
\Omega^{-1} \mathbf{c m}^{-2} \mathbf{s}^{0.5}\end{array}$ & $\begin{array}{l}E_{\text {SIE }} \\
(\%)\end{array}$ \\
\hline Blank & 89.68 & 2.769 & 0.669 & 254.727 & 0.319 & 0.781 & 6.033 & 1.100 & 2.769 & 567 & - \\
\hline $10^{-2} \mathrm{M}$ & 83.57 & 91.740 & 0.678 & 30.482 & 12.897 & 0.893 & 6.004 & 1.105 & 104.637 & - & 97 \\
\hline
\end{tabular}

From Tables 2 and 3, it is noted that the values of $R_{\mathrm{p}}$ in the blank solution decrease remarkably during immersion, whereas, $C_{\mathrm{dl}}$ value increases [24]. Thus, a long immersion time increases the possibilities of aggressive species to attack the copper surface, probably leading to the accumulation of the charges.

However, $R_{\mathrm{p}}$ corresponding to $10^{-2} \mathrm{M}$ DMTD, after $24 \mathrm{~h}$ immersion, is slightly lower than that obtained after $1 \mathrm{~h}$ immersion. The decrease of $R_{\mathrm{p}}$ value after $24 \mathrm{~h}$ compared with $1 \mathrm{~h}$ is probably originated from a partial desorption of DMTD molecules from copper surface [24], or a weakening of the adsorbed film implying the increase of available active sites number. Otherwise, if compared to the blank solution, the $R_{\mathrm{p}}$ values for $24 \mathrm{~h}$ are 
remarkably higher. The inhibition efficiency of DMTD is enhanced with immersion time reaching a maximum value of $97 \%$ at $24 \mathrm{~h}$.

As shown in Table 3, the thickness d calculated from EIS measurements increases with DMTD concentrations in $0.1 \mathrm{M} \mathrm{NaCl}$ solution. This evolution was also obtained in previous work devoted to investigate PDTC inhibitive effect on copper in $0.1 \mathrm{~mol} / \mathrm{L} \mathrm{[30]}$. However, it can be noted that the thickness of the formed film decreased with the increase of immersion time in the presence of $10^{-2} \mathrm{M}$ DMTD. In this case, it can be suggested that DMTD molecules are possibly desorbed from copper surface after $24 \mathrm{~h}$ immersion time.

\subsection{SEM/EDX characterization}

To obtain further investigations concerning the behavior of copper in $0.1 \mathrm{M} \mathrm{NaCl}$ with and without $10^{-2} \mathrm{M}$ DMTD, the morphological studies were carried out using SEM characterization coupled with EDX analysis. Figure 9 presents SEM micrograph and its high-magnification along with EDX, revealing copper surface state after $24 \mathrm{~h}$ immersion time in the studied solution at $298 \mathrm{~K}$. It is noteworthy to mention that samples were tied up using conductive adhesive tape containing carbon, which gave arise to the appearance of small trace of carbon within EDX analysis.

According to SEM images taken after exposure of copper in $0.1 \mathrm{M} \mathrm{NaCl}$, it is observed that the surface is much damaged and rough. This can be explained by the presence of corrosion products on copper surface. Additionally, some scratches appear on copper surface resulting from the used abrasive paper.

EDX analysis assess the SEM observations by indicating signals ascribed to $\mathrm{Cu}, \mathrm{O}$, and small amount of Cl. Similar results were found elsewhere [42]. This is in a good agreement with previous elementary analysis showing some typical composition of the formed corrosion products, mainly attributed to $\mathrm{Cu}_{2} \mathrm{O}$ and $\mathrm{CuCl}[60]$.

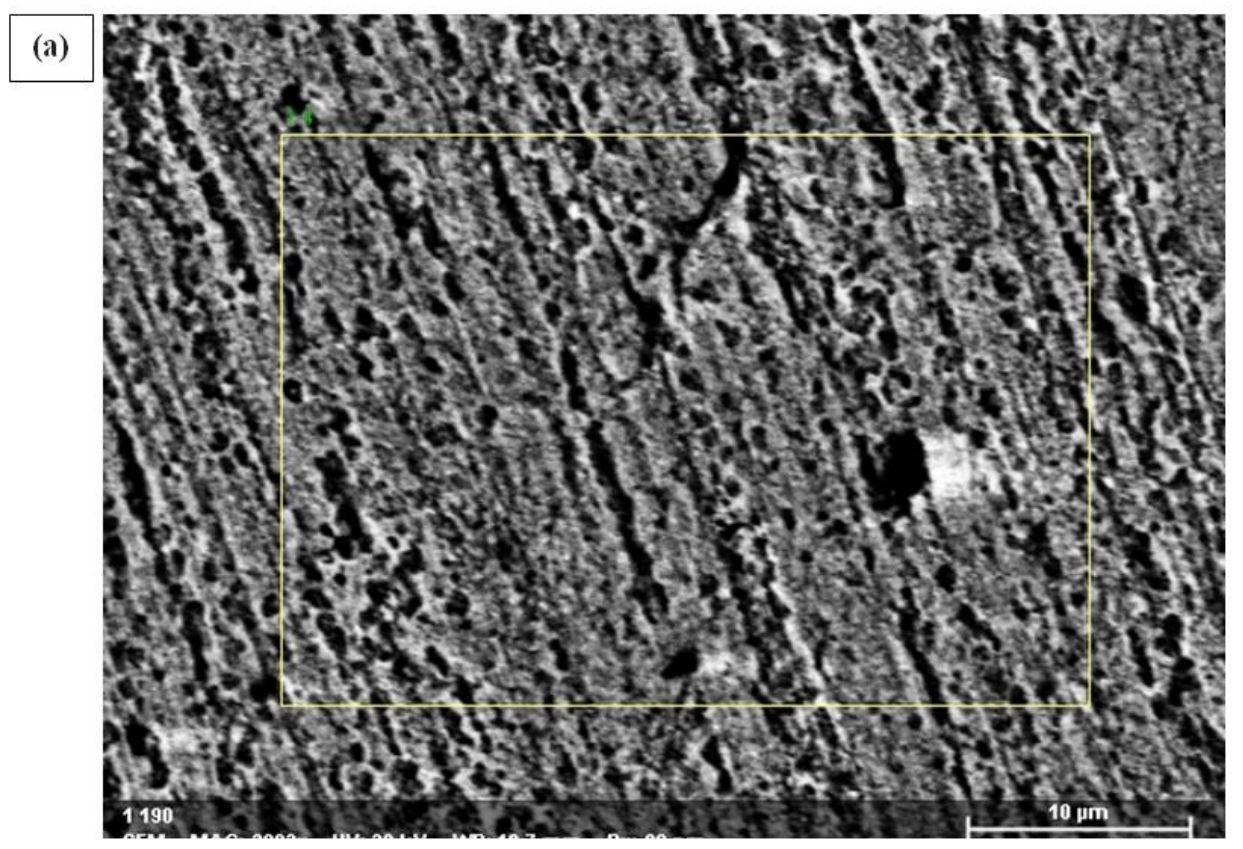



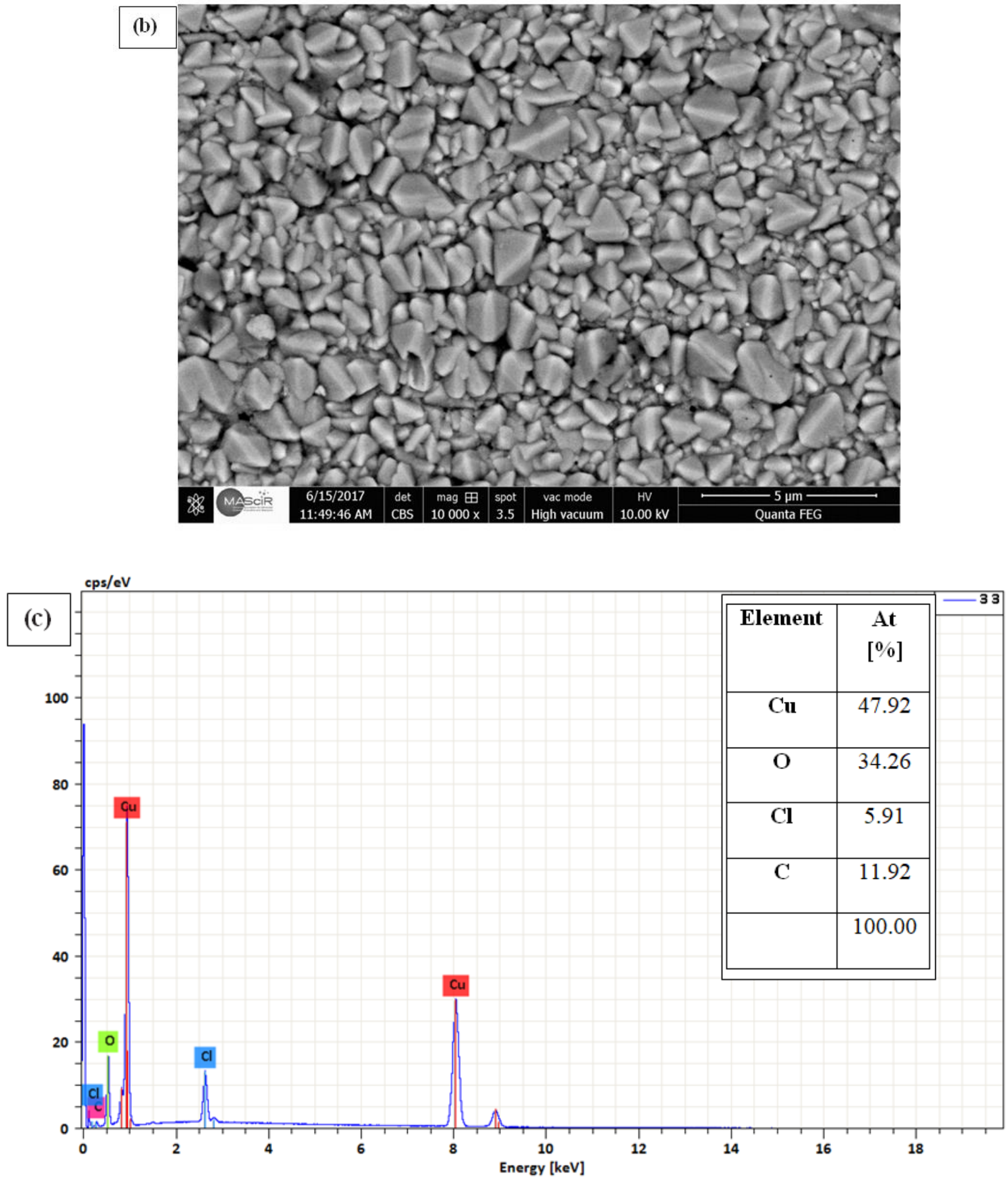

Figure 10. SEM micrograph of copper surface after $24 \mathrm{~h}$ immersion in $0.1 \mathrm{M} \mathrm{NaCl}$ (a) $10 \mu \mathrm{m}$, (b) $5 \mu \mathrm{m}$ and (c) EDX analysis. 

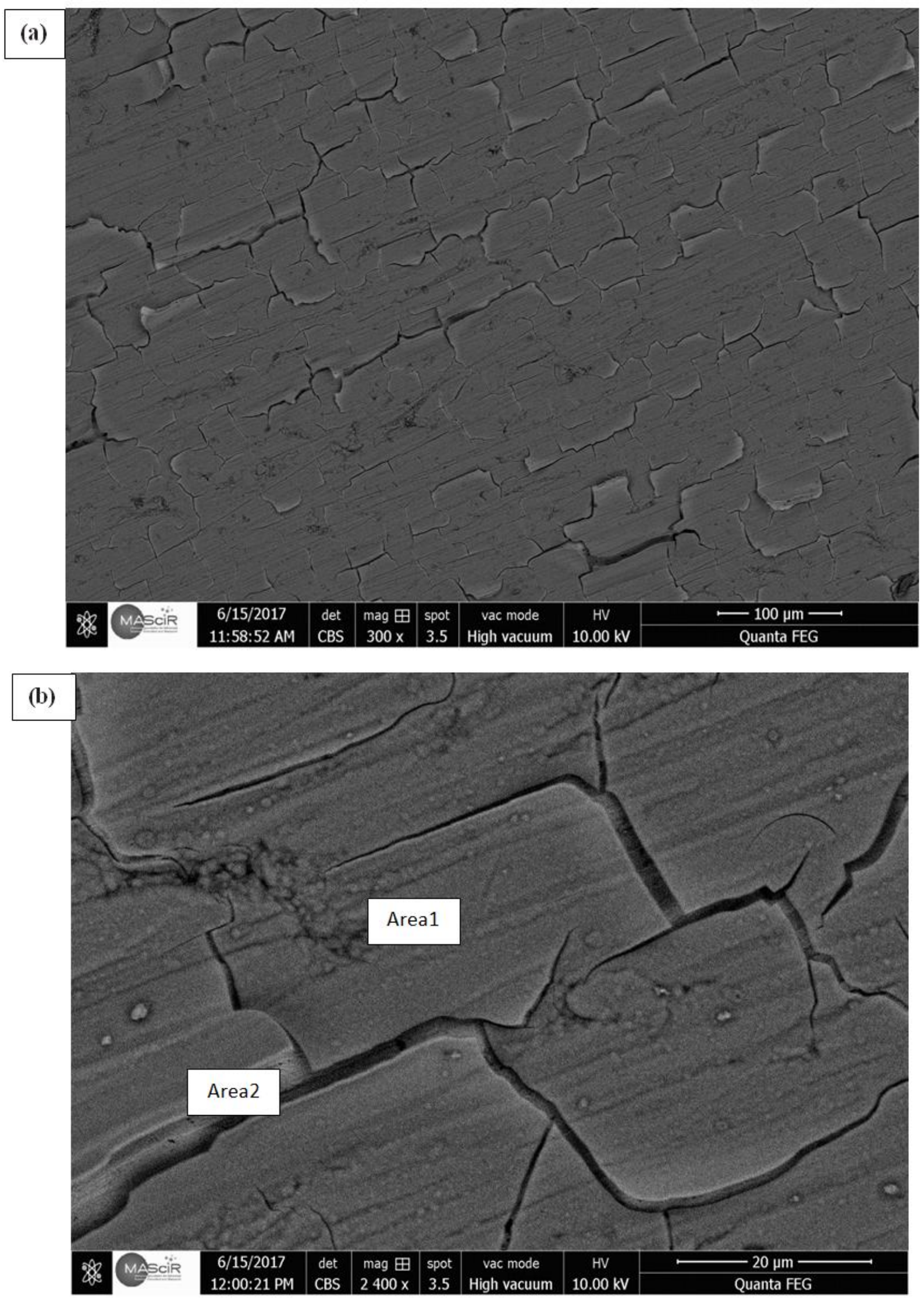

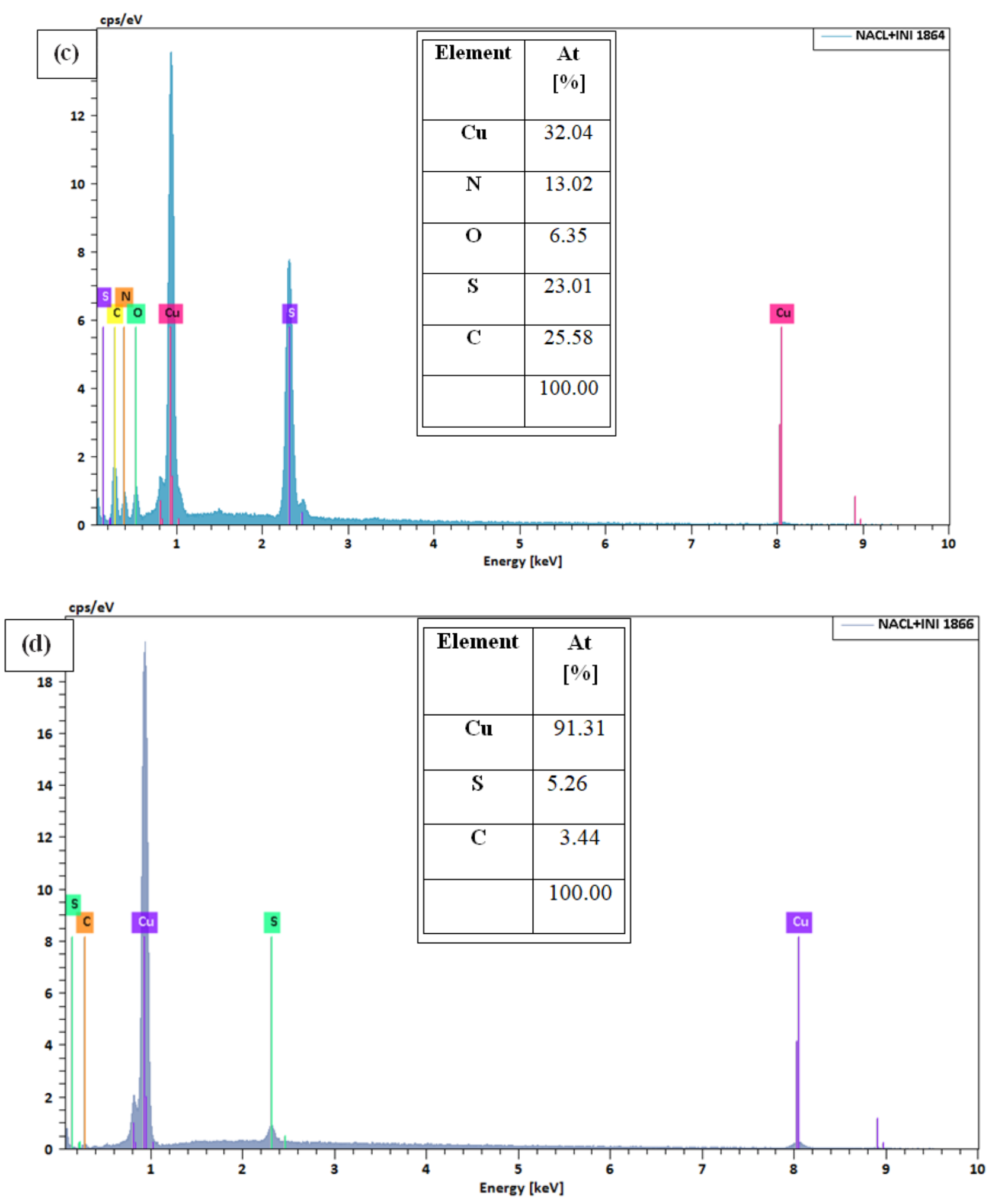

Figure 11. SEM micrograph of copper surface after $24 \mathrm{~h}$ immersion in $0.1 \mathrm{M} \mathrm{NaCl}+10^{-2} \mathrm{M}$ DMTD. (a) $100 \mu \mathrm{m}$, (b) $20 \mu \mathrm{m}$, (c) EDX analysis of Area 1, (d) EDX analysis of Area 2. 
Figure 11 presents the SEM micrograph of copper surface after $24 \mathrm{~h}$ immersion in $0.1 \mathrm{M} \mathrm{NaCl}+10^{-2} \mathrm{M}$ DMTD. It can be noticed that the surface is not attacked if compared to that observed in the blank test solution.

The EDX investigation of Area 1 indicates high signal of $\mathrm{S}, \mathrm{N}$ and $\mathrm{C}$ peaks. This is more likely due to the adsorption of DMTD through the interaction, mainly between the atom related to the highest signal, namely sulfur, and copper surface. Therefore, one may suggest that the surface is protected by the adsorbed DMTD film as reported elsewhere [56].

Moreover, a very weak peak of oxygen is detected by EDX analysis of the Area 1 and no peak is attributed to $\mathrm{Cl}$, suggesting that the adsorption was fast and hindered the formation of oxides and $\mathrm{CuCl}[31,61]$. The small fraction of oxygen in this area might result from the prior formation of copper oxide layer formed by the existence of oxygen in the solution and/or due to hydrolysis of $\mathrm{CuCl}[1,62]$.

In order to have deep insight under the formed inhibitory film, SEM micrographs of Area 2 were also performed. It can be seen that copper surface consists of crevices in Area 2. EDX analysis shows the presence of only copper and small amount of sulfur. The ratio $\mathrm{S} / \mathrm{Cu}$ is 12 times lower than Area 1 indicating a lower DMTD content. The presence of only $\mathrm{Cu}$ peaks even in the crevices confirms that indeed the adsorption of DMTD prevents completely the formation of corrosion products.

\subsection{XRD patterns}

Figure 12 shows XRD patterns collected after $24 \mathrm{~h}$ immersion of copper samples in the blank test solution without or with $10^{-2} \mathrm{M}$ DMTD at $298 \mathrm{~K}$. Without DMTD, corrosion products, such as nantokite $(\mathrm{CuCl})$ and crystalline cuprite $\left(\mathrm{Cu}_{2} \mathrm{O}\right)$, were detected as represented by smaller and significant peaks. This is confirmed by SEM/EDX characterization where corrosion products are predominantly $\mathrm{Cu}, \mathrm{O}$ with low amount of $\mathrm{Cl}$. $\mathrm{Cu}_{2} \mathrm{O}$ is the main corrosion product along with minor presence of $\mathrm{CuCl}[63,64]$.

As for the spectrum obtained with DMTD, $\mathrm{Cu}_{2} \mathrm{O}$ and $\mathrm{CuCl}$ peaks are no longer apparent and only typical peaks of $\mathrm{Cu}$ remain on the XRD diagram. This might be related to the adsorption of DMTD film preventing the formation of corrosion compounds. Moreover, the non appearance of new peaks may be due to the non crystallization of DMTD layer, which was well interpreted previously [31]. In previous study conducted on PDTC effect on bronze surface using SEM/EDX investigations, it was showed that at high concentrations of PDTC, oxides formation was hindered due to PDTC adsorption through the interaction between sulfur atoms and bronze sites [61]. 


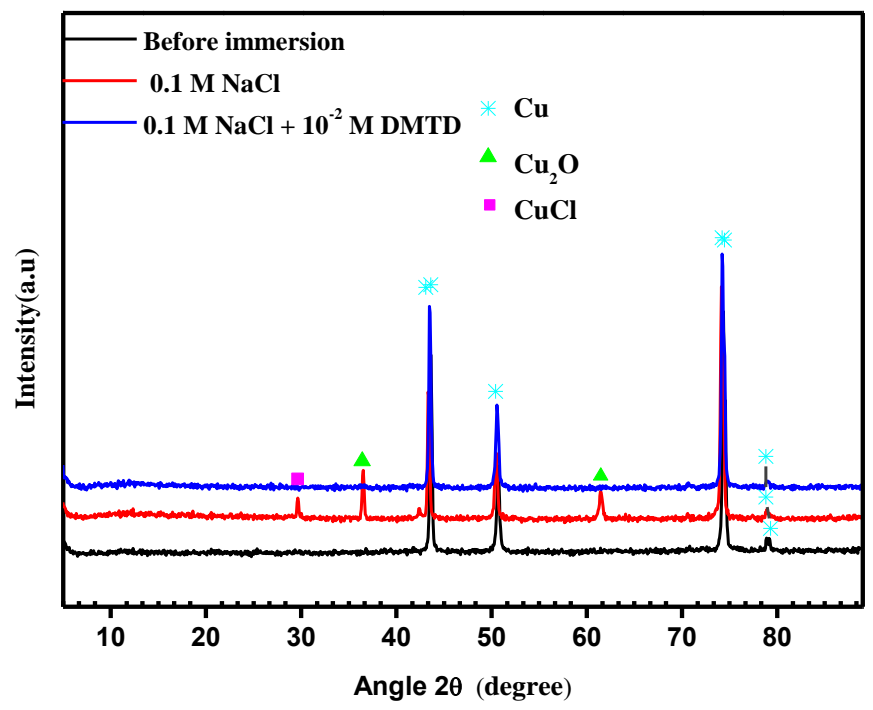

Figure 12. XRD pattern recorded on the copper surface after $24 \mathrm{~h}$ immersion in $0.1 \mathrm{M} \mathrm{NaCl}$ without or with $10^{-2} \mathrm{M}$ DMTD.

\subsection{Contact Angle measurements}

To verify whether the adsorption of DMTD compound onto copper surface has occurred, contact angle measurements of water were conducted on copper surface and copper immersed during $24 \mathrm{~h}$ in $0.1 \mathrm{M} \mathrm{NaCl}$ solution without or with $10^{-2} \mathrm{M}$ DMTD. Figure 13 shows the sessile drop water on the studied surfaces. It is noticed that the polished copper surface indicates hydrophobicity behavior with an angle of $74.77^{\circ}$, this contact angle is probably ascribed to the oxides on the surface as mentioned by previous studies [65]. Practically, the same value was determined in other works [66]. However, the contact angle has drastically decreased up to $49.16^{\circ}$ when the copper surface was exposed to the blank test solution. Parook et al. found a value of $28.3^{\circ}$ and attributed the low contact angle to the breaking and/or depassivation of copper oxide layer which probably led to increase the hardness of copper surface, and consequently the water drop expanded instantaneously [65].

Copper surface studied in $0.1 \mathrm{M} \mathrm{NaCl}$ solution containing $10^{-2} \mathrm{M}$ DMTD shows a relative increase in contact angle $\left(75.69^{\circ}\right)$ if compared to the non attacked surface. This is more likely justified by DMTD adsorption onto the surface. Elsewhere, similar hydrophobicity behavior occurred with BTAH inhibitor in $3.5 \% \mathrm{NaCl}$ and was explained by the presence of an adsorbed hydrophobic film of BTAH on copper surface [65]. In the same way, it can be assumed that DMTD film formed on copper surface is of a hydrophobic nature. 

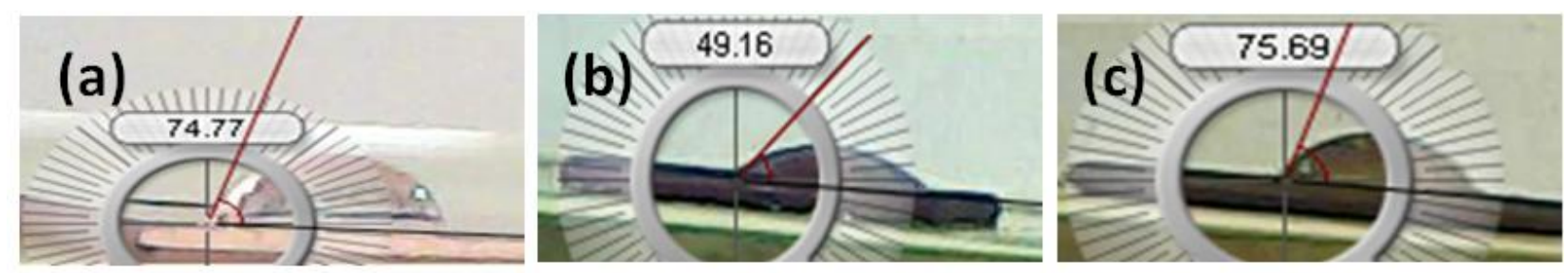

Figure 13. Water contact angles (a) before immersion and after $24 \mathrm{~h}$ immersion in $0.1 \mathrm{M} \mathrm{NaCl}$ solution (b) in the absence and (c) the presence of $10^{-2}$ M DMTD in the solution.

\subsection{ICP-AES results}

After one month exposure tests of copper sheets in $0.1 \mathrm{M} \mathrm{NaCl}$ solution, without and with $10^{-2} \mathrm{M}$ DMTD, the amount of $\mathrm{Cu}^{2+}$ ions released in the solution is determined by ICPAES technique, which is claimed to have several advantages as mentioned by M.A. Amin et al. [8]. Figure 14 illustrates the quantitative measurements results of $\mathrm{Cu}^{2+}$ ions quantity released in both solutions. One can clearly see that the dissolved copper amounts obtained are around $0.727 \mathrm{mg} / \mathrm{L}$ and $0.105 \mathrm{mg} / \mathrm{L}$ in absence and presence of DMTD in the solution, respectively. The low dissolution of copper in the solution containing DMTD is related to the decrease of metal ions diffusion from the metal surface into the electrolyte solution as reported by literature [67]. On the other hand, Lei et al. stated that the dissolution rate of covered electrode surface by PPy-IP6, was found to be lower than the bare substrate immersed during 900 hours in a solution containing 3.5\% $\mathrm{NaCl}$ [68]. This observation is related to the formation of a DMTD film on copper surface which prevents the contact between the solution and the studied surface. Hence, this result confirms the adsorption of the protective film on the surface, which is well explained in earlier studies by the adsorption of the molecules on the sample surface [69].

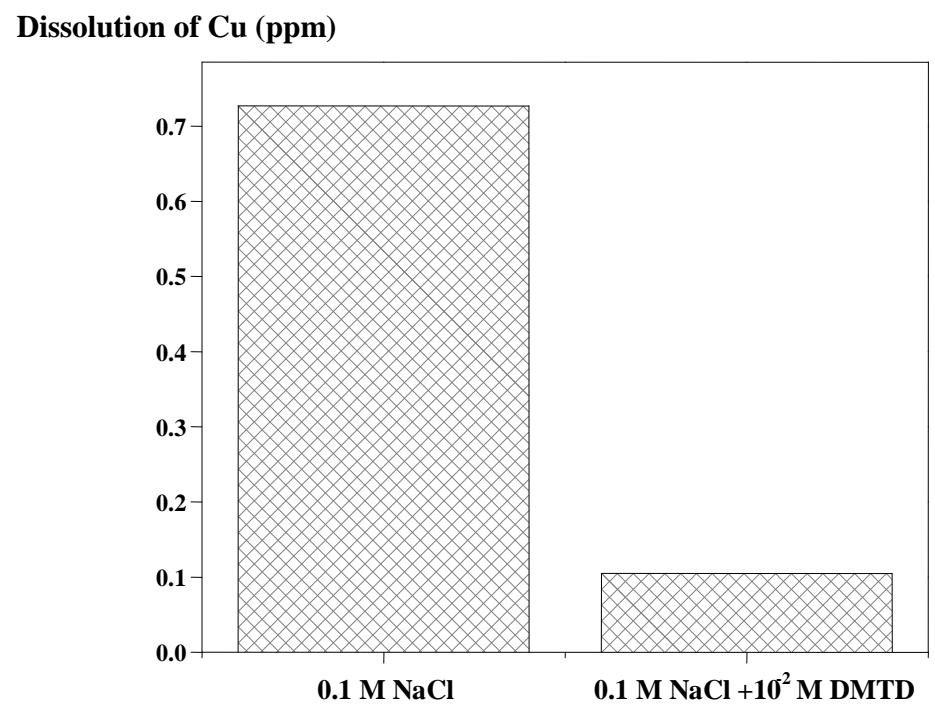

Figure 14. Dissolution of $\mathrm{Cu}(\mathrm{ppm})$ after one month immersion tests of copper in $0.1 \mathrm{M} \mathrm{NaCl}$ with and without $10^{-2}$ M DMTD. 


\subsection{Ion chromatography (IC) results}

Ion chromatography was used to quantify chloride anions concentration after one month exposure in the absence and presence of DMTD in the test solution. In the DMTD free solution, the concentration of chloride ions after corrosion process exhibits lower values if compared to the solution containing $10^{-2}$ M DMTD. The values obtained are $3477.78 \mathrm{mg} / \mathrm{L}$ and $3531.35 \mathrm{mg} / \mathrm{L}$ in the absence and presence of $10^{-2} \mathrm{M}$ DMTD respectively. The lower amount of chloride ions within the corrosive solution is owing to the adsorption $\mathrm{of}^{-}$on copper surface which led to the formation of corrosion products containing $\mathrm{Cl}$. This is already reported by EDX results displayed in Figure 10, where the presence of $\mathrm{Cl}$ atom signal is depicted.

The change in chloride ions concentration in the presence of DMTD suggests that this compound acts as a physical barrier or a competitor to $\mathrm{Cl}^{-}$for available adsorption sites on copper surface. This points out that DMTD must be readily adsorbed on copper surface by forming a protective film hindering the adsorption of $\mathrm{Cl}^{-}$. Similar results were reported by A.M. Shah et al. [67] investigations on copper corrosion inhibition by MT inhibitor.

\section{Conclusions}

From the results obtained in this study, dealing with DMTD effect on $\mathrm{Cu}$ corrosion in $0.1 \mathrm{M} \mathrm{NaCl}$ medium, several conclusions can be drawn:

1. Potentiodynamic polarization measurements show that DMTD exhibits an excellent performance against copper corrosion in chloride media and acts as a mixed inhibitor, decreasing both anodic and cathodic processes.

2. EIS measurements results highlight the improvement of the inhibitive efficiency with increasing DMTD concentration which reaches its maximum up to 24 hours immersion. This result, originated from a large increase in the surface film resistance as a function of DMTD concentration, reveals that DMTD is a good inhibitor for copper corrosion in $0.1 \mathrm{M} \mathrm{NaCl}$ solution.

3. SEM surface analysis exhibit a good coverage of the DMTD molecules on copper surface and reveals that this compound prevents copper corrosion by the formation of a thin and very protective film, hindering the formation of oxides as confirmed by XRD results. EDX analysis indicates that DMTD is bonded with copper surface through sulfur atoms. XRD and CA results reveal that DMTD film is amorphous and relatively hydrophobic.

4. Electrolyte analysis using ICP-AES and IC techniques show that the presence of DMTD in the solution reduces copper dissolution and acts as a physical barrier or a competitor to chloride for available adsorption sites. 


\section{References}

1. A. El Warraky, H.A. El Shayeb and E.M. Sherif, Anti-Corros. Methods Mater., 2004, 51, no. 1, 52-61. doi: $10.1108 / 00035590410512735$

2. A.L. Bacarella and J.C. Griess, J. Electrochem. Soc., 1973, 120, 459-465.

3. G. Kear, B.D. Barker and F.C. Walsh, Corros. Sci., 2004, 46, no. 1, 109-135. doi: 10.1016/S0010-938X(02)00257-3

4. J.L. Lei, L. Lj, S. Zhang, S.M. Cai, D. Li and M. Z. Yang, Acta Chim. Sin., 2001, 59, no. 8, 1216-1221.

5. G.D. Zhou, H. Shao and B.H. Loo, J. Electroanal. Chem., 1997, 421, 129-135. doi: 10.1016/0022-0728(94)03577-P

6. M. Finšgar and D.K. Merl, Corros. Sci., 2014, 83, 164-175. doi: 10.1016/j.corsci.2014.02.016

7. G. Tansuğ, T. Tüken, E.S. Giray, G. Findikkiran, G. Siğircik, O. Demirkol and M. Erbil, Corros. Sci., 2014, 84, 21-29. doi: 10.1016/j.corsci.2014.03.004

8. M.A. Amin and K.F. Khaled, Corros. Sci., 2010, 52, no. 4, 1194-1204. doi: 10.1016/j.corsci.2009.12.035

9. S.B. Adeloju and H.C. Hughes, Corros. Sci., 1986, 26, no. 10, 851-870. doi: 10.1016/0010-938X(86)90068-5

10. T. Suter, E.M. Moser and H. Böhni, Corros. Sci., 1993, 34, no. 7, 1111-1122. doi: 10.1016/0010-938X(93)90292-O

11. N. Souissi and E. Triki, Corros. Sci., 2008, 50, no. 1, 231-241. doi: 10.1016/j.corsci.2007.06.022

12. C. Blanc, S. Gastaud and G. Mankowski, J. Electrochem. Soc., 2003, 150, no. 8, B396. doi: $\underline{10.1149 / 1.1590327}$

13. M. Scendo, Corros. Sci., 2008, 50, no. 6, 1584-1592. doi: 10.1016/j.corsci.2008.02.015

14. E.A. Skrypnikova, S.A. Kaluzhina, L.E. Agafonova, Int. J. Corros. Scale Inhib., 2014, 3, no. 1, 59-65. doi: 10.17675/2305-6894-2014-3-1-059-065

15. E.A. Skrypnikova and S.A. Kaluzhina, Int. J. Corros. Scale Inhib., 2017, 6, no. 2, 142 150. doi: $10.17675 / 2305-6894-2017-6-2-4$

16. E.A. Skrypnikova and S.A. Kaluzhina, Int. J. Corros. Scale Inhib., 2015, 4, no. 2, 139145. doi: $10.17675 / 2305-6894-2015-4-1-139-145$

17. A. Frignani, F. Zucchi, G. Trabanelli and C. Monticelli, Int. J. Corros. Scale Inhib., 2015, 4, no. 1, 96-107. doi: 10.17675/2305-6894-2015-4-1-096-107

18. I.A. Arkhipushkin, L.P. Kazansky, S.S. Vesely and Y.E. Pronin, Int. J. Corros. Scale Inhib., 2014, 3, no. 2, 78-88. doi: 10.17675/2305-6894-2014-3-2-078-088

19. M. Erbil, Corrosion, 1991, 3, 13.

20. G. Kilinççeker, B. Yazici, A.B. Yilmaz and M. Erbil, Mater. Chem. Phys., 2002, 119, no. 1-2, 30-39. doi: 10.1016/j.matchemphys.2009.07.040 
21. T. Hoepner and S. Lattemann, Desalination, 2002, 152, 133-140. doi: 10.1016/S00119164(02)01056-1

22. M.M. Antonijevic and M.B. Petrovic, 2008, 3, 1-28. doi: 10.1016/j.ijengsci.2004.12.001

23. A. Fateh, M. Aliofkhazraei and A.R. Rezvanian, Arab. J. Chem., 2017 (in press). doi: 10.1016/j.arabjc.2017.05.021

24. M. Yadav and D. Sharma, Indian J. Chem. Technol., 2010, 17, March, 95-101.

25. I. Dugdale and J.B. Cotton, Corros. Sci., 1963, 3, 69-74. doi: 10.1016/S0010938X(63)80001-3

26. R. Walker, Corrosion (NACE), 1975, 31, no. 3, 97-100. doi: 10.5006/0010-9312$\underline{32.10 .414}$

27. U.R. Evans, The Corrosion and Oxidation of Metals, First Supplementary Volume, St. Martin's Press, New York, 1968.

28. J. Izquierdo, J.J. Santana, S. González and R.M. Souto, Prog. Org. Coat., 2012, 74, no. 3, 526-533. doi: 10.1016/j.porgcoat.2012.01.019

29. D.Q. Zhang, L.X. Gao and G.D. Zhou, Corros. Sci., 2004, 46, no. 12, 3031-3040. doi: 10.1016/j.corsci.2004.04.012

30. W. Qafsaoui, M.W. Kendig, H. Perrot and H. Takenouti, Electrochim. Acta, 2013, 87, 348-360. doi: 10.1016/j.electacta.2012.09.056

31. W. Qafsaoui, M.W. Kendig, S. Joiret, H. Perrot and H. Takenouti, Corros. Sci., 2016, 106, 96-107. doi: 10.1016/j.corsci.2016.01.029.

32. M. Kidwai, P. Misra, K.R. Bhushan and B. Dave, Synth. Commun., 2000, 30, no. 16, 3031-3040. doi: 10.1081/SCC-200030958

33. E.M. Sherif and S.Park, Electrochim. Acta, 2006, 51, 6556-6562. doi: 10.1016/j.electacta.2006.04.047

34. L. Valek and S. Martinez, Mater. Lett., 2007, 61, no. 1, 148-151. doi: 10.1016/j.matlet.2006.04.024

35. M. Kendig, M. Hon and J. Sinko, ECS Trans., 2006, 1, no. 9, 119-129. doi: $\underline{10.1149 / 1.2215583}$

36. H. Baeza, M. Guzmán, P. Ortega and L. Vera, J. Chil. Chem. Soc., 2003, 48, no. 3, 23.

37. T.T. Qin, J. Li, H.Q. Luo, M. Li and N. Bing, Corros. Sci., 2011, 53, 1072-1078. doi: 10.1016/j.corsci.2010.12.002

38. W. Qafsaoui, M. Kendig, H. Takenouti and F. Huet, ECS Trans., 2008, 27, no. 13, 123-132. doi: $\underline{10.1038 / 10834}$

39. W. Qafsaoui, G. Mankowski and F. Dabosi, Corros. Sci., 1993, 34, no. 1, 17-25. doi: $\underline{10.1016 / 0010-938 X(93) 90255-\mathrm{F}}$

40. V.F. Lucey, Br. Corros. J., 1972, 7, no. 1, 36-41. doi: 10.1179/000705972798323332

41. W. Qafsaoui, M.W. Kendig, H. Perrot and H. Takenouti, Corros. Sci., 2015, 92, 245255. doi: $10.1016 /$ j.corsci.2014.12.011 
42. Z. Khiati, A.A. Othman, M. Sanchez-Moreno, M.C. Bernard, S. Joiret, E.M.M. Sutter and V. Vivier, Corros. Sci., 2011, 53, no. 10, 3092-3099. doi: 10.1016/j.corsci.2011.05.042

43. S. Hong, W. Chen, Y. Zhang, H.Q. Luo, M. Li and N.B. Li, Corros. Sci., 2013, 66, 308-314. doi: 10.1016/j.corsci.2012.09.034

44. K.F. Khaled, S.S. Abdel-Rehim and G.B. Sakr, Arabian. J. Chem., 2012, 5, no. 2, $213-$ 218. doi: $10.1016 /$ j.arabjc. 2010.08 .015

45. S. Hong, W. Chen, H.Q. Luo, N.B. Li，Corros. Sci., 2012， 57， 270-278. doi: 10.1016/j.corsci.2011.12.009

46. G. Sığırcık, D. Yildirim, T. Tüken, Corros. Sci., 2017， 120, 184-193. doi: $\underline{\text { 10.1016/j.corsci.2017.03.003 }}$

47. L. Feng, S. Zhang, Y. Qiang, Y. Xu, L. Guo, L.H. Madkour and S. Chen, Materials (Basel), 2018, 11, no. 6, 1042. doi: 10.3390/ma11061042

48. W. Li, X. Bai, F. Yang and B. Hou, Int. J. Electrochem. Sci., 2012, 7, no. 3, 26802694.

49. H.M. Abd El-Lateef, A.M. Abu-Dief, L.H. Abdel-Rahman, E.C. Sañudo and N. Aliaga-Alcalde, J. Electroanal. Chem., 2015, 743, April, 120-133. doi: 10.1016/j.jelechem.2015.02.023

50. Ž.Z. Tasić, M.B. Petrović Mihajlović, M.B. Radovanović, A.T. Simonović and M.M. Antonijević, J. Mol. Struct., 2018, 1159, 5 May, 46-54. doi: 10.1016/j.molstruc.2018.01.031

51. I.D. Raistrick, D.R. Franceschetti and J.R. Macdonald, In Impedance Spectroscopy: Theory, Experiment and Applications, 2nd ed., Ed. E. Barsoukov and J.R. Maconald, John Wiley \& Sons, Inc., Hoboken, New Jersey, 2005.

52. C. Noguet, C. Schwab, C. Sennett, M. Sieskind, C. Noguet, C. Schwab, C. Sennett, M. Sieskind and C. Viel, J. Phys., 1965, 26, 317.

53. G.J. Brug, A.L.G. Van Den Eden, M. Sluyters-Rehbach and J.H. Sluyters, J. Electroanal. Chem., 1984, 176, 275-295.

54. Y. Qiang, S. Zhang, L. Guo, X. Zheng, B. Xiang and S. Chen, Corros. Sci., 2017, 119, 68-78. doi: $10.1016 /$ j.corsci.2017.02.021

55. M.M. Solomon and S.A. Umoren, Meas. J. Int. Meas. Confed., 2015, 76, 104-116. doi: $10.1016 /$ j.measurement.2015.08.029

56. M. Ormellese, L. Lazzari, S. Goidanich, G. Fumagalli and A. Brenna, Corros. Sci., 2009, 51, no. 12, 2959-2968. doi: 10.1016/j.corsci.2009.08.018

57. L. Valek, S. Martinez, D. Mikulić, I. Brnardić, Corros. Sci., 2008, 50, no. 9, 27052709. doi: 10.1016/j.corsci.2008.06.018

58. S. Gudić, E.E. Oguzie, A. Radonić, L. Vrsalović, I. Smoljko and M. Kliškić, Maced. J. Chem. Chem. Eng., 2014, 33, no. 1, 13-25. doi: 10.1149/1.2018254

59. K.F. Khaled, Mater. Chem. Phys., 2008, 112, no. 1, 104-111. doi: 10.1016/j.matchemphys.2008.05.052 
60. A. Krätschmer, I. Odnevall Wallinder and C. Leygraf, Corros. Sci., 2002, 44, no. 3, 425-450. doi: 10.1016/S0010-938X(01)00081-6

61. W. Qafsaoui, A.E. Taouil, M.W. Kendig, H. Cachet, S. Joiret, H. Perrot and H. Takenouti, Corros. Sci., 2018, 130, July 2017, 190-202. doi: 10.1016/j.corsci.2017.10.034

62. E.M. Sherif and S.-M. Park, J. Electrochem. Soc., 2005, 152, no. 10, B428. doi: $\underline{10.1149 / 1.2018254}$

63. X. Liao, F. Cao, L. Zheng, W. Liu, A. Chen, J. Zhang and C. Cao, Corros. Sci., 2011, 53, no. 10, 3289-3298. doi: 10.1016/j.corsci.2011.06.004

64. R.P.B. Hernández, Z. Pászti, H.G. de Melo and I.V. Aoki, Corros. Sci., 2010, 52, no. 3, 826-837. doi: $10.1016 /$ j.corsci.2009.11.003

65. P.F. Khan, V. Shanthi, R.K. Babu, S. Muralidharan and R.C. Barik, J. Environ. Chem. Eng., 2015, 3, no. 1, 10-19. doi: 10.1016/j.jece.2014.11.005

66. B.V. Appa Rao, M. Y. Iqbal and B. Sreedhar, Electrochim. Acta, 2010, 55, no. 3, 620631. doi: $10.1016 /$ j.electacta.2009.09.007

67. A.M. Shah, A.A. Rahim, S.A. Hamid and S. Yahya, Int. J. Electrochem. Sci., 2013, 8, no. 2, 2140-2153.

68. Y.H. Lei, N. Sheng, A. Hyono, M. Ueda and T. Ohtsuka, Corros. Sci., 2013, 76, 302309. doi: $10.1016 /$ j.corsci.2013.07.003

69. S. Ramesh, S. Rajeswari, S. Maruthamuthu, Appl. Surf. Sci., 2004, 229, no. 1-4, $214-$ 225. doi: $\underline{10.1016 / j . a p s u s c .2004 .01 .063}$ 